\title{
The Heterogeneous Accentuation of Economic Content In Vocational Education: A Starting Point for Occupation-Specific Human Resource Development
}

\author{
Christoph Maus \\ RWTH Aachen University, School of Business and Economics \\ maus@wiwi.rwth-aachen.de
}

Background and Purpose: Since the successive introduction of "learning field" oriented curricula in Germany, teaching at vocational schools as part of the dual system has been based on concrete actions. The underlying curricula describe business-oriented learning fields. The translating of these learning fields into pedagogical learning situations is the responsibility of the vocational curriculum conferences at the individual vocational school level, whereby con-siderable leeway is afforded them in these activities. This means that, despite there being an identical curricular basis, it is possible for individual schools to apply heterogeneous content emphases within the education programmes for commercial vocations. This study examines the correlation between such heterogeneous content with regard to the subject of economics and the person characteristics of the relevant teachers.

Design/Methodology/Approach: In order to determine the individual significance of eco-nomics curricula as part of the education programme for commercial occupations on a learning field basis, an online survey was conducted among commerce teachers. Descriptive statements about the significance of topics of content are generated with the help of the relevance ratings provided by the respondent teachers.

Results: The findings for the correlations indicate a relationship between the relevance of economics content and individual experience of teaching staff with regard to that particular academic discipline, because a high relevance rating correlates with individual tangencies within the teacher's educational biography

Conclusion: The shifting of lesson content design onto the individual vocational schools has resulted in human resource determinant factors coming into force. Apart from a (fully desira-ble) heterogeneity of content, these factors have also led to a decrease of economics content.

Keywords: education, economic education, curriculum, learning fields, institutionalized human resource development

\section{Introduction: Current Situation}

In Germany, the curricular foundations for vocational schools are elaborated centrally by the Standing Conference of the Ministers of Education and Cultural Affairs of the Länder (KMK), hereafter "Standing Conference", but on account of that country's federalist educational structure, the curricula are implemented by the individual federal states (Länder). Up to the mid-1990s, all curricula were structured according to academic subjects, so that teaching was conducted in conventional, subject-focussed lessons. But since 1996, the Standing Conference's structural guidelines for curricula have been replaced by action oriented framework curricula and implemented in the 
meantime by the individual Länder (cf. Reetz/Seyd 2006 p. 227). In this paper, we focus on vocational school curricula for commercial occupations that require education/ training in Germany. The redesigning of the curricula was undertaken in a step-by-step way over the years and was completed in 2013. Thus, all currently relevant curricula for vocational schools have a "learning field" oriented structure (cf. Standing Conference of the Ministers of Education and Cultural Affairs of the federal states, 2013).

\section{How Learning Field Based Curricula Are Structured}

The newly designed curricula for vocational teaching are based on vocational learning fields, which themselves have been derived from vocational "action fields".

"Learning fields are didactically prepared fields of activity. They are competency-based and indicate what a learner should actually be able to do in a vocational action field after having completed a learning field. This is expressed in the form of a goal formulation" (Sloane, 2003, p. $4 .{ }^{1}$, cf. also Standing Conference of the Ministers of Education and Cultural Affairs of the federal states, 2011, p. 10ff.).

In a work context, systematically organized sub- ject-specific knowledge is not usually called for, whereas specialized competencies relevant to a particular occupation are. ${ }^{2}$ The curricular goal is now that of depicting vocational actions within the relevant curricula (cf. Mathes 2011, p. 374; Czycholl/Ebner 2006, p. 45). This means that the systematic handling of academic subjects is neglected. Knowledge and action comprise in equal measures the determinants of curricular content implementation (cf. Fischer/Seeber 2014, p. 10f.; Wilbers 2014, p. 62 ff.: Nickolaus 2014, p. 1ff.; Nickolaus 2011, p. 159f.: Czycholl/Ebner 2006, p. 44ff.: Reetz/Seyd 2006, p. 247; Straka 2006, p. 151f.);

"Action competency is perceived to be the willingness and the ability of individuals to conduct themselves in professional, societal and private situations in an appropriate and individually and socially responsible manner". ${ }^{3}$ (Standing Conference of the Ministers of Education and Cultural Affairs of the federal states, 2011, p. 31).

In all curricula, the learning fields are identically broken down into the items "Goal Formulation" and "Contents", as exemplified by learning field no. 8- "Analyzing and Evaluating Annual Financial Statements" as part of the vocational education programme for Industriekaufmann/ Industriekauffrau (industrial office clerk) (cf. Standing Conference of the Ministers of Education and Cultural Affairs of the federal states, 2002, p. 16).On an individual

Table 1: How a learning field is structured as exemplified by learning field No. 8 of the vocational education programme for Industriekaufmann/Industriekauffrau (Industrial Office Clerk).

\section{Learning field no. 8: Analyzing an Annual Financial Statement \\ Year 2 of Education Programme \\ Standard duration: 80 lessons}

\section{Goal formulation:}

Students work on an annual financial statement and make assessment decisions under consideration of corporate interests and current accounting provisions. They prepare the statements, determine factors to assess companies and draw conclusions for company policy. They also analyze the statement from the view point of an external observer. Students select appropriate media for their work, present their results and give reasons for their decisions.

\section{Content:}

Valuation approaches for assets and for debts according to commercial law and fiscal law, acquisition costs and production costs.

Valuation principles - prudence principle, shareholder principle

Open reserves and undisclosed reserves

Factors of asset structure and capital structure, liquidity, equity to fixed assets ratio, profitability

Cash flow

Means of presentation

1 Author's own translation

2 With reference to the concept of Fachkompetenz ("professional competency"), cf. Dubs 2006, p. 167 ff.; Min-nameier 2006, p. 391; Pätzold 2006, p. 174 ff.; Tramm 2003, p. 2f. and with reference to the relationship be-tween Wissen ("knowledge") and Wissensanwendung (“application of knowledge”), cf. Nickolaus 2014, p. 3; Nickolaus/Petsch/Norwig 2013, p. 539; Nickolaus/Seeber 2013, p. 166ff., Gschwendtner/Abele/Nickolaus 2009, p. 575. For a detailed differentiation between the concept of education and the concepts of competence and qualification, cf. Reinisch 2006, p. 259ff.; Beutner/Schaumann/Twardy 2006, p. 289ff. and as a summary Baethge/Baethge-Kinsky 2006, p. $153 \mathrm{ff}$.

3 Author's own translation 
vocational school level, it is the task of the school to translate the action oriented guidelines into pedagogical learning situations. Content emphases may - and indeed should - vary, depending on the occupation being trained for (cf. Straßer 2013, p. 497ff.). Thus, different content emphases can be placed within identical education programmes. Owing to Germany having a "dual" vocational education system, the impacts of this aspect go beyond the domain of the vocational schools and extend into the occupational human resource development of real companies, since curricularly implemented content may be heterogeneously distributed amongst a company's human capital.

The objective of this study is, then, to examine the influence that person characteristics related to the teaching of economics have on the relevance attributed to economics content. These person characteristics come into effective play within the scope of the leeway that is present in the learning situation structure. In this context, professional teaching experience and studying business and economics as part of a teaching degree serve as person characteristics, both of them producing differentiated results with regard to economics curricula.

\section{Economics in the Framework of Ac- tion Oriented Curricula for Commercial Vocational Education}

The reason for limiting this analysis to economics content areas stems from the classification of economics content into education-theoretical categories. The topic of economics teaching has - similarly to many of its related content fields - a bipolar nature ranging from aspects of general education with regard to an individual's own lifestyle $^{4}$ across to vocational or career-related education in the context of commercial vocational profiles (cf. German Federal Ministry of Education and Research, 2005, $\$ 1$, Para. 3). ${ }^{5}$ There is a direct relevance between economics and commercial vocational education, but only a limited action oriented relevance for individual occupations, whereby the degree of intensity varies between the different occupational profiles as well as within a particular occupational profile. Prior to the introduction of learning field based curricula, there was an autonomous discipline of "economics" with its own specific subject curriculum that ranged across the various education programmes. The current learning field oriented curricula have resulted in an integrative implementation of economics-related content within the framework of the subject "economic and social processes" (or "general economics" in the vocational education programme for bank clerks (Bankkauffrau/ Bankkaufmann), cf. German Ministry of Education, 2004, p. 10). Thus, no homogeneous foundations exist between the commercial vocational programmes; on the contrary, these vary according to the individual occupational profiles, so it can be assumed that economics content is subject to heterogeneous implementation. ${ }^{6}$ The heterogeneous curricular foundations for economics-related content fields that have emerged over time enable an observation of both structural and content-related changes within the educational canon for commercial vocational education that have resulted from the implementation of the learning field approach. At the same time, content emphases can be derived from action oriented content within action oriented learning fields.

\section{Methodology of the Analysis}

To date, questions pertaining to the content variance of learning field structured vocational education programmes have rarely been systematically addressed. In the following, the curricular leeway afforded to the vocational curricula conferences and the teachers provides the starting point for researching the impacts stemming from the implementation of learning field oriented curricula on the relevance of the subject "economics".

\subsection{Generation of Hypotheses}

Theory-based paradigms for developing professional expertise promote stepwise models which link competency growth to factors in a teacher's own educational biography and incorporate both of them into individual development

4 Within the framework of the discussed concept of economics education, this is also a key task of any vocation-al school. Cf. Korunka/Frank 2005, p. 25f.; Loerwald/Schröder 2011, p. 9ff.; Retzmann 2011, p. 15ff.; May 2011, p. 3ff.; Tramm/Seeber 2006, p. $274 \mathrm{f}$.

5 The relationship between the concepts of "commercial education" and "economics education" is described by Fischer/Seeber, who state that there is interaction between the two. Whereas "economics" does not represent reality, strictly speaking, but constructs models of reality, commercial education is related to situational learning (Fischer/Seeber 2014, p. 5).

6 Economics content is thus, on account of the introduction of learning field based curricula, affected at a con-tent-related level (vocational action orientation) and at a structural level (integration into the subject "economic and social processes").

7 Whereas Fuller/Brown evaluate the individual problems and concerns of teachers in relation to their professional experience, identifying three different stages of development ("survival stage", "mastery stage" and "routine stage"), cf. Fuller/Brown 1975, p. $25 \mathrm{ff}$.), Sikes et al. develop typical stages of experience dependent on the age of the teacher (cf. Schönknecht 2005, p. 3). Huberman proceeds similarly, but links the different stages to years of professional experience rather than age of the teacher (cf. Huberman 1988, p. 119ff.). 
stages (cf. Schönknecht 2005, p. 2ff.). ${ }^{7}$ Different levels of experience as a determinant of teaching practice have been subject to premise-derived questions in earlier research. For instance, Götzl et al. (2013, p. 12) examined the significance of professional experience for organizational teaching factors by observing selected social forms, lessons and real learning time in relation to professional experience.

Another analysis looked at whether there are differences in the way students perceive a lesson in relation to the professional experience of a teacher (cf. Berliner 1992, p. $227 \mathrm{ff}$.) or whether the professional experience of a teacher has an impact on the learning success of the student being taught. However, no significant correlations were found (cf. Lipowsky 2006, p. 54), so that "the professional experience of a teacher plays a somewhat minor role with regard to the learning success of a student and is difficult to interpret as an independent variable"8 (Lipowsky 2006, p. 54). Different professional experience levels have already been examined in relation to organizational characteristics of teaching, but personal attitudes about subject-related content dependent on teaching experience have not to date been examined (cf. Götzl et al. 2013, p. 12 f.). ${ }^{9}$

Within the framework of the autonomous subject "economics", there are differences in the educational biographies of the relevant teachers, which become evident in the designing of their own lessons. The earlier existence of the academic subject "economics" and the corresponding curricula before the introduction in Germany of the learning field based approach, means that more experienced teachers actually taught the subject of economics in vocational schools, whilst their younger colleagues do not have the same experience.

Under model-theoretic premises, this signifies that structural differences flow into potential model stages and make a noticeable impact on the relevance rating. In the present case being examined here, the assumption was that a teacher's own experience of teaching "economics" as an autonomous subject could have an impact on the implemented content of the learning fields. Thus, the following Hypothesis 1 was derived:

Hypothesis 1: "Teachers with teaching experience in the autonomous subject of "economics" attribute a higher relevance to the corresponding content also in the learning field approach than do their colleagues who do not have such experience".
Theoretical models for developing pedagogical professional knowledge describe its development in dependency on problem solving processes. Whilst Bereiter/Scardamalia (2007) focus on cognitive resources being released when problem-solving processes are repeated - which may then be used for future tasks of more complexity, Ericsson/ Charness (1994) use the non-intrinsic goal of individual performance enhancement to help to explain the growth of professional knowledge (following Brunner/Kunter/ Krauss et al. 2006, p. 526). What both approaches share in common is the assumption that experience data alone do not suffice to explain domain-specific professional knowledge, and that cognitive and motivational resources must be appropriately used (cf. Brunner/Kunter/Krauss et al. 2006, p. 526).

Translated into structures of economics teaching, one can assume that potential differences in relevance may be a result of different learning opportunities, which arise particularly during teacher training programmes at university. In this context, research has to date not brought forth any clear-cut findings with regard to a correlation between the discipline-related educational level of teachers and their teaching performance. As there are differences related to the observed discipline being taught ${ }^{10}$, this analysis will examine potential correlations between different preparatory training structures for teaching economics and current topic-related relevance measuring.

Those teachers who have taken a teaching degree specializing in business and economics are grouped together. In a teaching degree programme that specializes in business and economics, economics content is relevant for the examinations, so that we can assume that teachers who have taken such a degree will have had experience of economics content during their training. We contrast this group with a group of teachers who did not have components of business and economics in their teaching degree programme, teachers who were trained in disciplines other than business and economics and teachers who entered the profession by an alternate route. Analogously to the hypothesis on relevance observation, we have derived a second hypothesis:

Hypothesis 2: "Teachers who studied business and economics as part of their teaching degree rate the relevance of economic content more highly than teachers who did not".

8 Author's own translation

9 For the influence of professional experience of teachers outside of specialized subjects, cf. e.g. Schlichter 2012, p. 4 and 23; Lipowsky 2006, p. 53ff.; Wayne/Youngs 2006, p. 77, Schönknecht 2005, p. $19 \mathrm{f}$.

10 Uniform evidence that there are differences in pedagogical/psychological knowledge between teachers who took a teaching degree and those who became teachers via alternate routes can be found in various studies (cf. as a summary Kunina-Habenicht/ Schulze-Stocker/Kunter et al. 2013, p. 6, see also Zurstrassen 2009, p 40). For natural science subjects there are different findings (cf. Lagler/Wilhelm 2013, p. 50f.; Wayne/Youngs 2006, p. 86), whereby for the subject of mathematics, a significant positive correlation was found (Lagler/Wilhelm 2013, p. 49f.; Wayne/Youngs 2006, p. 86). For other subjects, however, findings were inconsistent, e.g. for history and English (Cf. Wayne/Youngs 2006, p. 86). 


\subsection{Methodological Approach}

In order to determine the individual significance of economics curricula as part of the education programme for commercial occupations on a learning field basis, an online survey was conducted among commerce teachers. All participants were male and female teachers who had been teaching at vocational schools of commerce in the German federal state of North Rhine Westphalia in the summer of 2014. All of them were teaching in programmes for selected commercial occupations as part of Germany's dual system of company training and vocational education. Consonant with a circular order issued by the German Ministry of Education (cf. German Ministry of Education 1996), the heads of all those vocational schools in North Rhine Westphalia which catered for the relevant commercial occupations were contacted, rather than the teachers themselves. The heads were requested to inform the relevant teachers about the opportunity to participate in the study.

No further selection of teaching staff was implemented, so that all of those teachers in the relative education programmes could be taken into consideration. The selection of occupations taught was determined by factors regarding the number of new training/apprenticeship contracts drawn up in the previous year. ${ }^{11}$ Using a 6-point scale, teachers were required to rate the teaching relevance of individual economics-related items. In accordance with a 5-point Likert scale, respondents could choose from "strongly disagree" across to "strongly agree".

A $6^{\text {th }}$ point was added in case a certain content area was not an integral part of the teaching programme. Between 0 and 5 points were allocated (starting with "topic not dealt with" and moving up to "high relevance"). ${ }^{12}$ The items were selected according to the content guidelines for the learning fields. To take account of individual teaching implementation, these were broken down into various content areas, as exemplified in table 2.

The curricularly specified content areas were taken unmodified from economics-oriented learning fields and serve as a topical point of reference. ${ }^{13}$ Owing to their low degree of abstraction, the topic areas were broken down further into more specific areas (see the five exemplified ones in table 2). These then serve as items to be evaluated by the survey participants, which means that it is possible to quantify different content accentuations within roughly structured content specifications as well as the content area within the whole learning field (via cumulation). Thus, each point within the curricular goal formulation forms the framework for further specifications of content, the relevance of which was to be rated by respondents. The whole survey questionnaire is structured analogously to this.

Descriptive statements about the significance of topics of content are generated with the help of the relevance ratings provided by the respondent teachers. It is possible to observe economics-related learning fields in the context of the entire curriculum for a particular occupation as well as individual topics in specific learning fields. ${ }^{14}$ By surveying personal characteristics, determinant factors are derived, which influence the translating of learning field based guidelines into individual learning situations and thus impact on the relevance of economic content in lessons. The focus in the evaluation is on different tangencies between current teachers with regard to their educational biographies and their current economics relevancy ratings.

\section{Selected Findings}

In order to examine a potential impact of teachers' experience on the relevance of economics content (Hypothesis 1), the analysis included participants with up to 20 years of teaching experience, and over 20 years of experience, so that only the latter group of respondents can have actually ever taught economics as an autonomous subject. ${ }^{15} \mathrm{~A}$ mean comparison of both groups showed a significant difference with regard to the status accorded to intervocational teaching of economics: ${ }^{16}$

11 Teachers were addressed who taught in vocational education programmes for the occupations of Automo-bilkauffrau/-mann ("automobile salesperson"), Bankkauffrau/-mann ("bank clerk"), Kauffrau/-mann im Einzel-handel ("retail trade salesperson"), Kauffrau/-mann im Groß- und Außenhandel ("wholesale and foreign trade salesperson"), Immobilienkauffrau/-mann ("real estate agent”), Industriekauffrau/-mann“ (“industrial clerk”), Speditionskauffrau/-mann ("forwarding/shipping agent”), Versicherungskauffrau/-mann ("insurance agent").

12 The constant rating scale, according to which participants can give their estimations, enables the comparison across several education programmes, independent of their individual learning field structures.

13 The topic area shown in table 2, "Price formation in perfect and imperfect markets" has been taken unchanged from learning field no. 6 in the vocational education programme for Bankkauffrau/-mann (bank clerk).

14 As the autonomous subject "economics" was implemented without differentiation between the different com-mercial vocations prior to the learning field approach, we do not differentiate here either at this point

15 The grouping according to 20 years of teaching experience is determined by the introductory date in Germany of learning field based curricula.

16 The mean values shown incorporate all of the examined mean values as well as all the items covered. A further breaking down into individual items with regard to content would not enable a comparison between all of the examined education programmes, because on account of vocational action orientation principles, individual topics are not implemented consistently throughout the curricula for specific programmes. A particular topic cannot be examined in all of the education programmes because, owing to the heterogeneity of content, no uniform reference basis exists despite the economics subject matter not being primarily occupation-specific. Moreover, with the help of total mean values, the study takes account of quantitative differences between the learning fields. 
Table 2: Example of a Questionnaire for learning field No. 6 in the vocational education programme for Bankkauffrau/-mann (Bank Clerk), (excerpt):

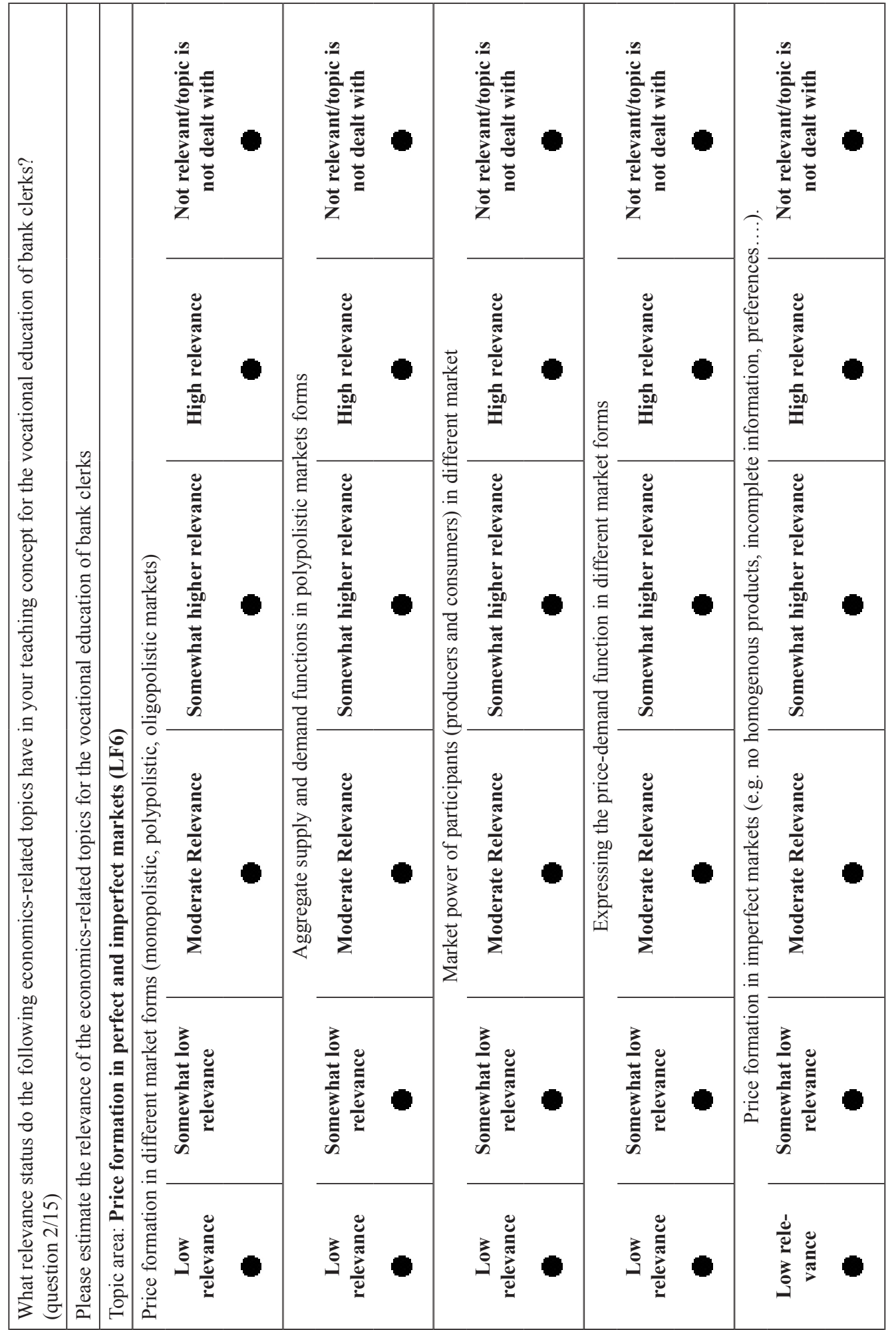


Table 3: Group results according to teaching experience

\begin{tabular}{|l|l|l|l|}
\hline Differentiator & Mean Value (MV) & Standard Deviation(SD) & Standard Error MV \\
\hline $\begin{array}{l}>20 \text { years of teaching } \\
\text { experience }\end{array}$ & 3.144 & .710 & .106 \\
\hline $\begin{array}{l}<20 \text { years of teaching } \\
\text { experience }\end{array}$ & 2.743 & .855 & .088 \\
\hline
\end{tabular}

Table 4: T-Test for mean value equality

\begin{tabular}{|l|l|l|l|l|l|l|}
\hline T & df & Sig. (2-sided) & MV-Difference & SD-Difference & \multicolumn{2}{|l|}{ 95\% Confidence Interval of Difference } \\
\cline { 6 - 7 } & & & & Lower & Upper \\
\hline 2.730 & 137 & .007 & .401 & .147 & .111 & .692 \\
\hline
\end{tabular}

With homogeneity of variance for both test groups (Levene's test: $\mathrm{F}=.193$; Sig. $=.141)$ there are significant variances (see Table 4).

The test group with at least 20 years of teaching experience rates the relevance of economics content moderately $(\mathrm{MV}=3.1)$. In contrast, the test group with less than 20 years' experience is lower ( $M V=2.7)$. For the group of more experienced teachers, we see lower variances $(n=45$; Var. $=.493)$ than for their younger colleagues $(n=94$, Var.=.722), showing that the relevance status is more homogenous the more experienced a teacher is. A comparison of the average rating per person reveals that about half of the more experienced teachers regard the relevance of economics content to be moderately important (rounded values: $55.56 \%$ ), whilst only $42.55 \%$ of their younger colleagues gave it that particular rating.

Whereas on average almost a third $(32.98 \%)$ of the younger teachers accord economics content a lower relevance ("Low relevance" $=3.19 \%$; "Somewhat low relevance" $=29.78 \%$ ), the corresponding group of more experienced teachers is only half as large at $15.55 \%$ ("Low relevance" $=4.44 \%$; "Somewhat low relevance" $=11.11 \%$ ). The significantly higher rating of an average of 0.4 points supports the assumption that the individual relevance accorded to economics-related topics increases if a teacher has actually taught economics as an autonomous subject. Clearly, a teacher's own experience of teaching the subject of economics influences his or her rating of the relevance of economics content.

A mean comparison to test the impact of having studied business and economics as part of a teaching degree programme on the rating of the relevance of economics content (Hypothesis 2) provides evidence for a differentiated relevance rating for economics content:

With homogeneity of variance (Levene's test: $\mathrm{F}=.942$; Sig. $=, 333$ ), there is a highly significant rating difference of 0.8 for those teachers who have studied economics themselves (Table 5).

The mean equality of both test groups supports the as- sumption. Whereas for those teachers who had studied business and economics ( $\mathrm{n}=108$; Var. $=.53$ ) we have an average value of 3.0, those teachers without a business and economics background the mean is $2.2(\mathrm{n}=30$; Var.=.69). A comparison of the average rating given by an individual shows that $51.54 \%$ of those teachers with a business and economics academic background rate the relevance of economic content moderately, whereby only $20.0 \%$ of those teachers with no economics background did likewise. This specific test group frequently gave lower relevance ratings $(69,97 \%$; Low relevance $=6.67 \%$; Somewhat low relevance $=63.33 \%$ ). In contrast, the more experienced colleagues gave lower relevance ratings of $18.69 \%$ (Low relevance $=2.80 \%$; Somewhat low relevance $=15.89 \%$ ). Thus, the assumption is supported that acceptance of economics content is more likely to be found among teachers who personally had experience of economics during their teaching degree programme.

\section{Findings and Deliberations}

The fact that the Standing Conference - with the help of subject-related learning fields - delegates the designing of curricula in a top-down process to the individual vocational schools in Germany implies that the vocational schools now have a broadened spectrum of tasks and areas of responsibility as well as more leeway in the framework of context factors for teaching (e.g. materials, equipment, specifications for the final Chamber of Industry and Commerce examination).

Whereas some years ago, the autonomous subject "economics" fulfilled a sort of "safety function" in the framework of curricula for commercial vocational education programmes, economics content in teaching is now subject to human resource determinants. With regard to human resource development, the findings of this study imply heterogeneous competence structures on the part of vocational school students. In particular, the implementa- 
Table 5: Group ratings differentiated according to whether teachers studied business and economics as part of their teaching degree

\begin{tabular}{|l|l|l|l|}
\hline Differentiator & Mean Value (MV) & Standard Deviation (SD) & Standard Error MV \\
\hline $\begin{array}{l}\text { Studied business \& } \\
\text { economics }\end{array}$ & 3.051 & .730 & .070 \\
\hline $\begin{array}{l}\text { Did not study business \& } \\
\text { economics }\end{array}$ & 2.197 & .840 & .153 \\
\hline
\end{tabular}

Table 6: T-Test for mean equality

\begin{tabular}{|l|l|l|l|l|l|l|}
\hline T & df & Sig. (2-sided) & MV Difference & SD Difference & \multicolumn{2}{|l|}{ 95\% Confidence Level of Difference } \\
\cline { 6 - 7 } & & & & .156 & .546 & Lower \\
\hline 5.482 & 136 & .000 & .854 & 1.162 \\
\hline
\end{tabular}

tion of economics models is made more difficult by the insistence on action oriented teaching structures - potentially resulting in an unwitting implementation of "second-class content" within a framework of career furtherance endeavours. The personal relevance assessments by the teachers provide a measure of the assessed value of economics content in teaching for commercial occupations.

The goal of the Standing Conference, i.e. to achieve action oriented teaching on the basis of a minimum curricular standard involves an increased activity orientation focussed on vocation-specific content and leads to economics content being embedded in integrated learning field and subject-related curricula. The relatively low relevance accorded to economics topics within the framework of the whole analysis provides evidence for a practical oriented loss of "prestige" of economics among teaching staff, which implies a theory-practice gap.

The findings for both correlations indicate a relationship between the relevance of economics content and individual experience of teaching staff with regard to that particular academic discipline, because a high relevance rating correlates with individual tangencies within the teacher's educational biography. In both evaluations, the more experienced group of teachers accords the individual subject-related contents significantly more relevance than does the respective comparison group, so that a teaching degree that incorporated business and economics results in a significantly more highly rated relevance than a teaching degree with other specializations but, however, does not produce noticeably higher ratings for the whole rating measurement. Also with regard to professional experience, there are significantly higher relevance ratings from the more experienced group than for the less experienced group, but no higher rating over the whole rating measurement.

A limitation of the findings of this study is that they only reflect the views of individual persons. Thus, processes that influence consensus finding within a vocational curriculum conference are not depicted. However, it is possible to derive tendencies regarding the handling of vocational curriculum conference results for the teaching of economics. Also, it must be taken into consideration that the reference basis of the survey is not oriented towards the implemented vocational school subject of economics, so that the findings here hold for the subject area of economics rather than for the curricularly specified subject "economic and social processes".

The shifting of lesson content design onto the individual vocational schools in the sense of a "human resource development" approach has resulted in human resource determinant factors coming into force. Apart from a (fully desirable) heterogeneity of content, these factors have also led to a decrease of economics content. The low relevance ratings suggest a practical orientation in line with minimum standards for content, so that the new curriculum structure is tantamount to a quantitative and qualitative decrease in the economics content. However, on account of the scale of measurement applied here, factorial intensity cannot be captured.

Apart from the desired and intended practical orientation, action oriented curricular design is having a side effect: teaching content is, some cases, changing. As a curricular starting point, the reference discipline is losing its significance to the benefit of a situative orientation, whereby both groups in this analysis are being affected by this transformation. On the level of individual teachers, lower relevance is accorded to economics content by those teachers whose teaching degree did not incorporate economics. As the "pro" economics teachers stem from the more experienced group, the demographic change will lead to those teachers who experienced the teaching of the autonomous subject "economics" exiting from the profession. Therefore, it is not likely that a qualitative enhancement of economics content in teaching will occur under the present framework conditions. For the trainees/apprentices, an action-oriented teaching concept goes hand in hand with a decrease in economics content in their vocational education programs. The influence of potential examination con- 
tent in the final examination held by the German Chamber of Industry and Commerce on the choice of teaching content in vocational school classes remains a topic for future investigation.

\section{References}

Baethge, M., \& Baethge-Kinsky, V. (2006). Ökonomie, Technik, Organisation: Zur Entwicklung von Qualifikationsstruktur und Qualifikationsprofilen von Fachkräften. In R. Arnold \& A. Lipsmeier (Ed.), Handbuch der Berufsbildung, 2nd Edition (pp. 153-173). Wiesbaden: VS Verlag für Sozialwissenschaften.

Berliner, D.C (1992). The nature of expertise in teaching. In: K.F Oser, A. Dick \& J.-L Patry (Ed.): Effective and responsible teaching: The new synthesis (pp. 227-248). San Francisco: Jossey Bass.

Beutner, M., Schaumann, U., \& Twardy, M. (2006). Neue Beruflichkeit und damit verbundene Anforderungen auf Basis des Kompetenzgedankens in der beruflichen Bildung. In G. Minnameier \& E. Wuttke (Ed.), Berufsund wirtschaftspädagogische Grundlagenforschung. Lehr-Lern-Prozesse und Kompetenzdiagnostik (pp. 289-304). Frankfurt am Main: Europäischer Verlag der Wissenschaften.

Brunner, M., Kunter, M., Krauss, S., Baumert, J., Blum, W., \& Dubberke, T. et al. (2006). Welche Zusammenhänge bestehen zwischen dem fachspezifischen Professionswissen von Mathematiklehrkräften und ihrer Ausbildung sowie beruflicher Fortbildung. Zeitschrift für Erziehungswissenschaft, 9(4), 521-544.

Czycholl, R., \& Ebner, H. (2006). Handlungsorientierung in der Berufsbildung. In R. Arnold \& A. Lipsmeier (Ed.); Handbuch der Berufsbildung; 2nd Edition (pp. 44-54). Wiesbaden: VS Verlag für Sozialwissenschaften.

Dubs, R. (2006). Bildungsstandards und kompetenzorientiertes Lernen. In G. Minnameier \& E. Wuttke (Ed.), Berufs- und wirtschaftspädagogische Grundlagenforschung. Lehr-Lern-Prozesse und Kompetenzdiagnostik (pp. 161-176). Frankfurt am Main: Europäischer Verlag der Wissenschaften.

Ericsson, K. A., \& Charness, N. (1994). Expert Performance, Its structure and Acquisition. American Psychologist, 49(8), 725-747, http://dx.doi.org/10.1037//0003-066X.49.8.725

Fischer, A., \& Seeber, S. (2014). Moderne kaufmännische Bildung - curriculare Zugänge und empirisch belastbare Kompetenzbestimmung. Berufs- und Wirtschaftspädagogik-online, Profil 3. Retrieved November 3, 2014, from http://www.bwpat.de/profil3/fischer_seeber_ profil3.pdf

Fuller, F., \& Brown, O. (1975). Becoming a teacher. In K. Ryan (Ed.), Teacher education. The seventy-fourth NSSE yearbook, Part II (pp. 25-52). Chicago: Univer- sity of Chicago Press.

Götzl, M., Jahn, R., \& Held, G. (2013). Bleibt alles anders!? Sozialformen, Unterrichtsphasen und echte Lernzeit im kaufmännischen Unterricht. Berufsund Wirtschaftspädagogik - online, (24). Retrieved November 10, 2014 from http:/www.bwpat.de/ ausgabe24/goetzl_etal_bwpat24.pdf

German Federal Ministry of Education and Research (2005). Berufsbildungsgesetz. BBIG, vom 07.09.2007. Retrieved November 3, 2014, from http://www.bmbf.de /pubRD/bbig.pdf

German Ministry of Education (2004). Lehrplan für das Berufskolleg in Nordrhein-Westfalen. Bankkauffrau/ Bankkaufmann. Fachklassen des dualen Systems der Berufsausbildung. Retrieved November 3, 2014 from http://www.berufsbildung.schulministerium.nrw. de/cms/upload/_lehrplaene/a/bankkaufleute.pdf

German Ministry of Education (1996): Durchführung empirischer Untersuchungen und Befragungen in Schulen, vom 20.06.1997. In: Bereinigte amtliche Sammlung der Schulvorschriften des Landes Nordrhein-Westfalen, 10 - 45 Nr. 2. Retrieved from http://www.berufsorientierung-nrw.de/cms/upload/BASS_10-45_Nr.2.pdf.

Gschwendtner, T., Abele, S., \& Nickolaus, R. (2009). Computersimulierte Arbeitsproben: Eine Validierungsstudie am Beispiel der Fehlerdiagnoseleistungen von Kfz-Mechatronikern. Zeitschrift für Berufs- und Wirtschaftspädagogik, 105(4), 557-578.

Huberman, M. (1988). Teacher careers and school improvement. Journal of Curriculum Studies, 20(2), pp. 119132, http://dx.doi.org/10.1080/0022027880200202

Korunka, C., \& Hermann, F. (2005). Ökonomische Bildung - Eine Ressource für die Entwicklung von ,Entrepreneurial Spirit‘. Wirtschaftspsychologie, 7(2), 24-41.

Kunina-Habenicht, O., Schulze-Stocker, F., Kunter, M. et al. (2013). Die Bedeutung der Lerngelegenheit im Lehramtsstudium und deren individuelle Nutzung für den Aufbau des bildungswissenschaftlichen Wissens. Zeitschrift für Pädagogik, 59(1), 1-23.

Lagler, E., \& Wilhelm, M. (2013). Zusammenhang von Schülerleistung und Fachausbildung der Lehrkräfte in den Naturwissenschaften - eine Pilotstudie in der Schweiz. Chimica et ceterae artes rerum naturae didacticae - Zeitschrift für die Didaktik aller Naturwissenschaften, 38(105), 47-70. Retrieved November 3, 2014 from http:/www.phlu.ch/ fileadmin/media/phlu.ch/dozierende/wil-

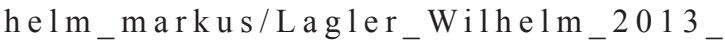
Lehrpersonenausbildung_und_Lernendenkenntnisse. pdf

Lipowsky, F. (2006). Auf den Lehrer kommt es an. Empirische Evidenzen für Zusammenhänge zwischen Lehrerkompetenzen, Lehrerhandeln und dem Lernen der Schüler. In C. Allemann-Ghionda \& E. Terhart (Ed.), Zeitschrift für Pädagogik, Beiheft 51 - Kompetenzen 
und Kompetenzentwicklung von Lehrerinnen und Lehrern (pp. 47-70). Weinheim: Beltz Verlag.

Loerwald, D., \& Schröder, R. (2011). Zur Institutionalisierung ökonomischer Bildung. Aus Politik und Zeitgeschichte, 12, pp. 9-15. Retrieved November 10, 2014, from www.bpb.de/system/files/pdf/EPCQ28.pdf

Mathes, C. (2011). Wirtschaft unterrichten. Methodik und Didaktik der Wirtschaftslehre. 7th Edition. Haan-Gruiten: Verlag Europa-Lehrmittel.

May, H. (2011). Ökonomische Bildung ist Allgemeinbildung. Aus Politik und Zeitgeschichte, 12, pp. 3-9. Retrieved November 3, 2014 from www.bpb.de/system/files/pdf/EPCQ28. pdf

Minnameier, G. (2006). Aspekte von ,Fachkompetenz - Kognitive Leistungen im Umgang mit Wissen. In G. Minnameier \& E. Wuttke (Ed.), Berufs- und wirtschaftspädagogische Grundlagenforschung. Lehr-Lern-Prozesse und Kompetenzdiagnostik (pp. 391-407). Frankfurt am Main: Europäischer Verlag der Wissenschaften.

Nickolaus, R. (2011). Didaktische Präferenzen in der beruflichen Bildung und ihre Tragfähigkeit. In Nickolaus, R. \& Pätzold,G. (Ed.), Zeitschrift für Berufs- und Wirtschaftspädagogik, Beiheft 25 - Lehr-Lernforschung in der gewerblich-technischen Berufsbildung (pp. 159175). Stuttgart, Franz Steiner.

Nickolaus, R. (2014). Anmerkungen zu Möglichkeiten und Grenzen einer empirischen Prüfung des Lernfeldkonzepts. Berufs- und Wirtschaftspädagogik - online, Profil 3. Retrieved November 3, 2014 from http:// www.bwpat.de/profil3/nickolaus_profil3.pdf

Nickolaus, R., Petsch, C. \& Norwig, K. (2013). Berufsfachliche Kompetenzen am Ende der Grundbildung in bautechnischen Berufen. Zeitschrift für Berufs- und Wirtschaftspädagogik, 109(4), 538-555.

Nickolaus, R., \& Seeber, S. (2013). Berufliche Kompetenzen: Modellierungen und diagnostische Verfahren. In A. Frey, U. Lissmann \& B. Schwarz (Ed.), Handbuch berufspädagogischer Diagnostik (pp. 166-195). Weinheim und Basel: Beltz Verlag.

Pätzold, G. (2006). Vermittlung von Fachkompetenz in der Berufsbildung. In R. Arnold \& A. Lipsmeier (Ed.), Handbuch der Berufsbildung, 2nd Edition (pp. 174190). Wiesbaden: VS Verlag für Sozialwissenschaften.

Reetz, L., \& Seyd, W. (2006). Curriculare Strukturen beruflicher Bildung. In R. Arnold \& A. Lipsmeier (Ed.); Handbuch der Berufsbildung, 2nd Edition (pp. 227259). Wiesbaden: VS Verlag für Sozialwissenschaften.

Reinisch, H. (2006). Kompetenz, Qualifikation und Bildung: Zum Diskurs über die begriffliche Fassung von Zielvorgaben für Lernprozesse. In G. Minnameier \& E. Wuttke (Ed.): Berufs- und wirtschaftspädagogische Grundlagenforschung. Lehr-Lern-Prozesse und Kompetenzdiagnostik (pp. 259-272). Frankfurt am Main:
Europäischer Verlag der Wissenschaften.

Retzmann, T. (2011). Kompetenzen und Standards der ökonomischen Bildung. Aus Politik und Zeitgeschichte, 12, pp. 15-21. Retrieved November 3, 2014 from www.bpb.de/ system/files/pdf/EPCQ28.pdf

Scardamalia, M., Bereiter, C. (2006). Knowledge building: Theory, pedagogy, and technology. In K. Sawyer (Ed.), The Cambridge handbook of the learning sciences (pp. 97-115). New York: Cambridge University Press.

Schlichter, N. (2012). Lehrerüberzeugungen zum Lehren und Lernen. Dissertation. Georg-August-Universität Göttingen. Retrieved November 3, 2014 from https://ediss.uni-goettingen.de/bitstream/handle/11858/00-1735-0000-000D-F0A6-8/schlichter.pdf? sequence $=1$

Schönknecht, G. (2005). Die Entwicklung der Innovationskompetenz von LehrerInnen aus (Berufs-)biographischer Perspektive. Berufs- und Wirtschaftspädagogik - online, Spezial 2. Retrieved November 10, 2014 from http://www.bwpat.de/spezial2/schoenknecht_ spezial2-bwpat.pdf

Sloane, P. F. E. (2003). Schulnahe Curriculumentwicklung. Berufs- und Wirtschaftspädagogik - online, 3(4). Retrieved from November 10,2014 fromhttp://www.bwpat.de/ ausgabe4/sloane_bwpat4.pdf

Standing Conference of the Ministers of Education and Cultural Affairs of the federal states (2002). Rahmenlehrplan für den Ausbildungsberuf Industriekaufmann / Industriekauffrau. Retrieved November 10, 2014 from http://www.kmk.org/fileadmin/pdf/Bildung/ BeruflicheBildung/rlp/industriekfm.pdf

Standing Conference of the Ministers of Education and Cultural Affairs of the federal states (2011). Handreichung für die Erarbeitung von Rahmenlehrplänen der Kultusministerkonferenz für den berufsbezogenen Unterricht in der Berufsschule und ihre Abstimmung mit Ausbildungsordnungen des Bundes für anerkannte Ausbildungsberufe, vom 23.09.2011. Retrieved November 3, 2014, from http://www.kmk.org/fileadmin/veroeffentlichungen beschluesse/2011/2011_09_23_GEP-Handreichung. pdf

Standing Conference of the Ministers of Education and Cultural Affairs of the federal states (2013). Rahmenlehrplan für den Ausbildungsberuf Kaufmann für Büromanagement und Kauffrau für Büromanagement. Retrieved November 3, 2014, from http:// www.kmk.org/fileadmin/pdf/Bildung/BeruflicheBildung/rlp/KaufmannBueromanagement13-09-27-E_01.pdf

Straka, G. A. (2006). ,Neue Lernformen' in der bundesdeutschen Berufsbildung - neue Konzepte oder neue Etiketten? In G. Minnameier \& E. Wuttke (Ed.), Berufs- und wirtschaftspädagogische Grundlagenfor- 
schung. Lehr-Lern-Prozesse und Kompetenzdiagnostik (pp. 145-159). Frankfurt am Main: Europäischer Verlag der Wissenschaften.

Straßer, P. (2013). Lernfelder - die (ungenutzte) Wiederkehr des Exemplarischen. Zeitschrift für Berufs- und Wirtschaftspädagogik, 109(4), 496-512.

Tramm, T. (2003). Zu Relevanz der Geschäftsprozessorientierung und zum Verhältnis von Wissenschaftsund Situationsbezug bei der Umsetzung des Lernfeldansatzes im kaufmännischen Bereich. Retrieved November 3, 2014, from http://www.dblernen.de/ archiv/tramm LF-geschaeftsprozessorientierung.pdf

Tramm, T. \& Seeber, S. (2006). Überlegungen und Analysen zur Spezifität kaufmännischer Kompetenz. In G. Minnameier \& E. Wuttke (Ed.), Berufs- und wirtschaftspädagogische Grundlagenforschung. Lehr-Lern-Prozesse und Kompetenzdiagnostik (pp. 273-288). Frankfurt am Main: Europäischer Verlag der Wissenschaften.

Wayne, A., \& Youngs, P. (2006). Die Art der Ausbildung von Lehrern und die Lerngewinne ihrer Schüler. Eine Übersicht über aktuelle empirische Forschung. In C.
Allemann-Ghionda \& E. Terhart (Ed.), Zeitschrift für Pädagogik, Beiheft 51 - Kompetenzen und Kompetenzentwicklung von Lehrerinnen und Lehrern (pp. 71-96). Weinheim: Beltz Verlag.

Wilbers, K. (2014). Wirtschaftsunterricht gestalten. Lehrbuch, 2nd Edition. Retrieved November 3, 2014, from http://www.pedocs. $\mathrm{de} /$ volltexte/2013/8420/pdf/Wilbers_2014_ Wirtschaftsunterricht_Lehrbuch_Aufl_2.pdf

Zurstrassen, B. (2009). Kompetenzorientierte Lehrerbildung in den sozialwissenschaftlichen Unterrichtsfächern: Blühende Landschaften in der sozialwissenschaftlichen Lehrerbildung von morgen? Journal of Social Science Education, 8(2), 32-45.

Christoph Maus graduated 2012 as a teacher of economics and German language at vocational colleges. Currently, he is a PhD student at the RWTH Aachen University, School of Business and Economics, Department of the Didactics of Economics. His research focuses on curricular structures within the commercial vocational education. 